\author{
M.Zh. Burkeev, G.M. Zhumanazarova, G.K. Kudaibergen, \\ E.M. Tazhbayev, G.A. Turlybek, E.Zh. Zhakupbekova \\ E.A. Buketov Karaganda State University, Kazakhstan \\ (E-mail: gaziza.zhumanazarova@mail.ru)
}

\title{
Research of the influence of external factors on copolymers based on unsaturated polyester resins
}

\begin{abstract}
The article is devoted to the research of the influence of external factors on copolymers based on poly (propylene fumarate phthalate) and acrylic acid. In this paper, the effect of organic solvents and $\mathrm{pH}$ of the medium on the rate of swelling of synthesized copolymers is studied. The rate of polymer swelling depends on many factors, including: the nature of the polymer and the solvent, the presence of electrolytes, changes in $\mathrm{pH}$ and ambient temperature, the molecular weight of the polymer, and so on. It is assumed that the polymer network of copolymers consists mostly of unsaturated polyester resin links. Research results show that the ratio of monomer units in the copolymer significantly affects the susceptibility of the polymer gel to the $\mathrm{pH}$ of the medium and the presence of organic solvents (DMSO, DMFA, ethanol). It is proved that changing the properties of the comonomer allows you to obtain hydrogels that can swell or collapse due to changes in the ionic strength or thermodynamic quality of the solution. By varying the ratio of comonomers of the links was adjusted by the intervals of the swelling and compression of the polymer networks. The molecular weight of poly (propylene fumarate phthalate)was determined by gel-penetrating chromatography. The identification and composition of copolymers were determined by IR spectroscopy and HPLC, respectively.
\end{abstract}

Keywords: polypropylene fumarate phthalate, acrylic acid, radical copolymerization, polar organic solvents, swelling, collapse, unsaturated polyester resin.

\section{Introduction}

Hydrogels are one of great interest in high-molecular compound research area in the recent decades, because these polymers able to swell in water by a several values from the original volume. Ability to absorb large amounts of water and bind dissolved low-molecular substances is a distinctive feature of these polymers. The primary quality of these polymers is the possession of macromolecular segment chain having hydrophilic properties of ionic and non-ionic or ampholytic nature [1-3]. Since the main hydrogel feature is the absorption of extremely large amounts of water, this impacts its structure which has a three-dimensional grid form. These grids structure resembles a linear polymer with sparse cross-linking points. In case of swelling in water distance between adjacent cross-linking points increases while the amount of the points remains the same. Such behavior allows hydrogels to absorb large amounts of water with massive volume change.

Unsaturated polyesters are promising polymeric systems creation chemical agents which are obtained from polyatomic alcohols and carboxylic acids by polycondensation. The key feature of unsaturated polyesters is high copolymerization reaction ability (curing behavior) with vinyl monomers at room temperature without high pressure or volatiles or other byproducts emission [4-8]. Due to this, unsaturated polyesters can be used as chemical agents for synthesizing «intelligent» polymers widely used in medicine, pharmaceutics, biotechnology and many other areas of the living environment.

Previously we have obtained and researched poly(propylene fumarate phtalate) based polymeric hydrogels with high absorbing abilities. Obtained results suggest prospects of their use as water sorbents in crop production [9] and efficient nanocatalysts [10]. However, it was interesting to continue researching in this area with a view to a comprehensive in-depth study of this unique and important group of materials.

This work is devoted to new polymers based on unsaturated polyester - poly(propylene fumarate phtalate) (p-PFP) with acrylic acid (AA) physical and chemical properties synthesis and research. Synthesized specimens have been analyzed for medium $\mathrm{pH}$ change, organic solvents and their concentration change, as well as initial composition of copolymers polymeric grid. 


\section{Experimental}

This article is a continuation of the work of the authors in this field (topic). The synthesis of an unsaturated polyester resin and the preparation of copolymers based on poly (propylene fumarate phthalate) are described in a previous article [13].

Cross-linked copolymer formation as result of p-PFP oligomeric molecule and AA radical copolymerization in presence of BP as initiating agent can be shown in the following diagram:

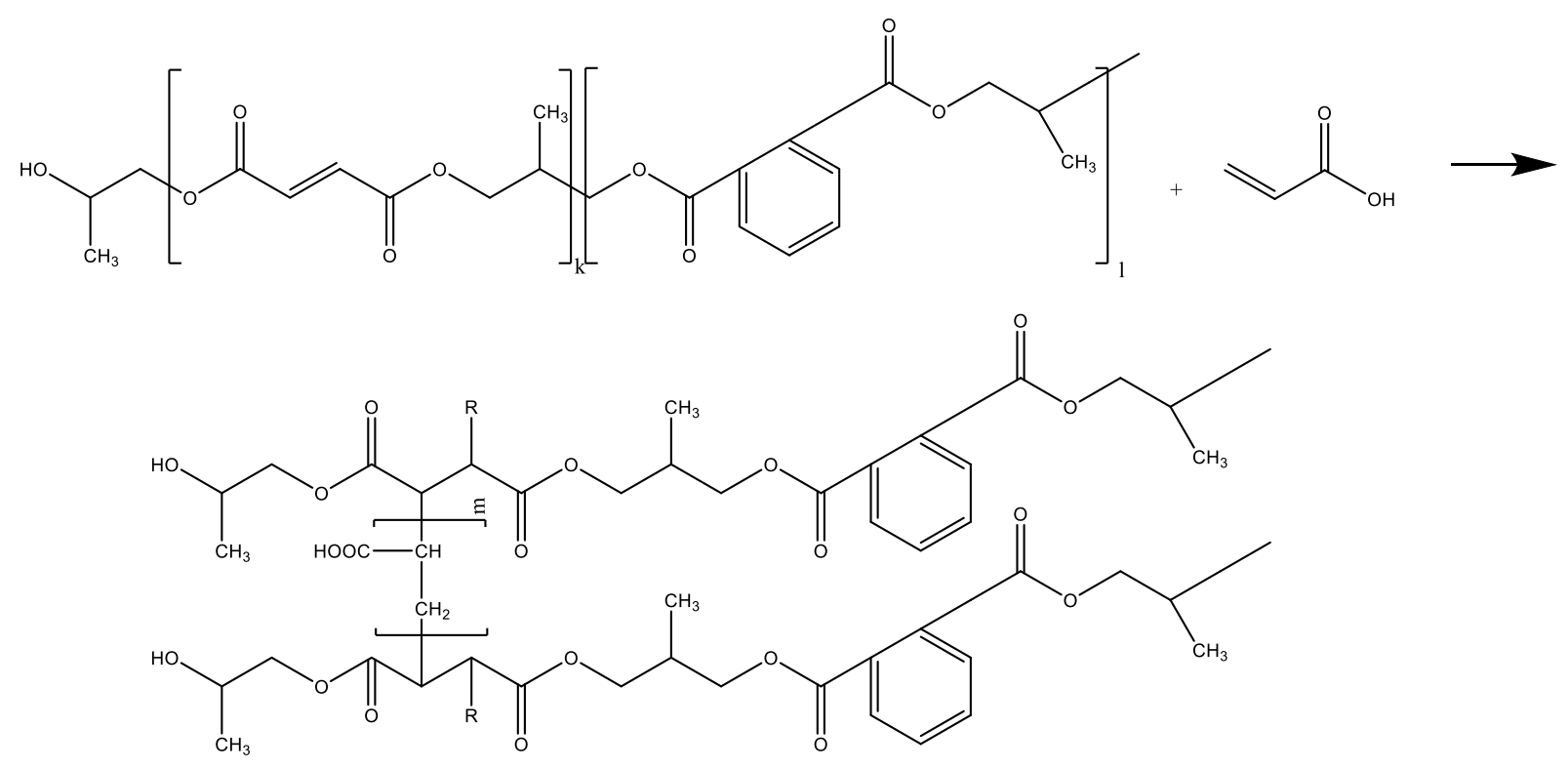

Figure 1. p-PFP and AA radical copolymerization

p-PFP molecular weight was defined by light scattering method at NACH 2100 AN nephelometer [14] and by gel-permeation chromatography, which is 2272 and 2394 atomic mass units.

Copolymers p-PFP and AA was identified by IR spectroscopy.

Contents of obtained copolymers were defined using high-efficient liquid chromatograph LC-20 Prominence by Shimadzu (Japan) $[15,16]$. In order to find amount of copolymers unreacted double bonds (degree of unsaturation) bromide-bromate method was used.

Hydrogel swelling equilibrium degree was defined by gravimetric method. Sample swelling rate $(\alpha)$ was calculated as ratio of swollen hydrogel mass at swelling equilibrium degree point to its initial mass in dry condition $[9,10]$.

DMSO, DMF and ethanol were taken as solvents. The choice of solvents was based on the polarity of the solvents.

\section{Result and Discussion}

The fundamental research related to radical copolymerization, which allows us to control the properties of polymers, their structure and molecular mass, and providing more ways to obtain the desired properties of polymers. As previously stated, the most desired products are unsaturated polyesters-based solidified with vinyl monomers; they have specific physical-chemical and physical-mechanical properties. The p-PFP molecules have unsaturated double bonds making which allows them to be used as a polymer matrix for obtaining cross-linked polymers during copolymerization with reactive acrylic acid.

p-PFP is obtained by fumaric acid, phthalic anhydride and propylene glycol polycondensation [11-13].

Cross-linked copolymer formation as result of p-PFP oligomeric molecule and AA radical copolymerization in presence of BP as initiating agent shown in the previous work of the authors [13]

p-PFP - AA copolymerization results are shown in Table 1 . Copolymer yield ranges from $83 \%$ to $62 \%$.

As seen in Table 1, copolymers are enriched with AA components throughout the range of initial mixtures; also, yield and swelling rate decrease at lower amounts of the latter. 
Table 1

Copolymer content dependence on initial mixture content in process of p-PFP (M1) and AA (M2) $[\mathrm{BP}]=\mathbf{8} \cdot \mathbf{1 0}^{-3} \mathrm{~mol} / \mathrm{m}^{3}, \mathrm{~T}=333 \mathrm{~K}$

\begin{tabular}{|c|c|c|c|c|}
\hline \multicolumn{2}{|c|}{ Initial monomer ratio, \% by mass } & \multicolumn{2}{|c|}{ Copolymer content, by mass } & \multirow{2}{*}{ Yield, $\%$} \\
\hline $\mathrm{M}_{1}$ & $\mathrm{M}_{2}$ & $\mathrm{M}_{1}$ & $\mathrm{M}_{1}$ & 83.70 \\
\hline 10.22 & 89.78 & 6.77 & 93.23 & 78.73 \\
\hline 25.00 & 75.00 & 20.34 & 79.66 & 79.33 \\
\hline 50.00 & 50.00 & 44.17 & 55.17 & 71.93 \\
\hline 73.91 & 26.09 & 68.42 & 31.58 & 62.09 \\
\hline 90.00 & 10.00 & 86.67 & 13.33 & \\
\hline
\end{tabular}

Copolymers were identified by IR spectrum data according to Figure 1 . Bands describing the range of $1450 \sim 1640 \mathrm{~cm}^{-1}$ are related to $\mathrm{C}=\mathrm{O}$ bond. Meanwhile, p-PFP-AA copolymers IR spectrum absorption bands at $1744 \mathrm{~cm}^{-1}$ and $2951 \mathrm{~cm}^{-1}$ describe $\mathrm{C}=\mathrm{O}$ and $-\mathrm{CH}_{2}$ bonds, respectively, and peaks at $1107 \sim 1172 \mathrm{~cm}^{-1}$ are typical for C-O-C bond. Besides, absorption bands at $1447 \mathrm{~cm}^{-1}$ and $1396 \mathrm{~cm}^{-1}$ relate to $-\mathrm{CH}\left(\mathrm{CH}_{2}\right)$ bond.

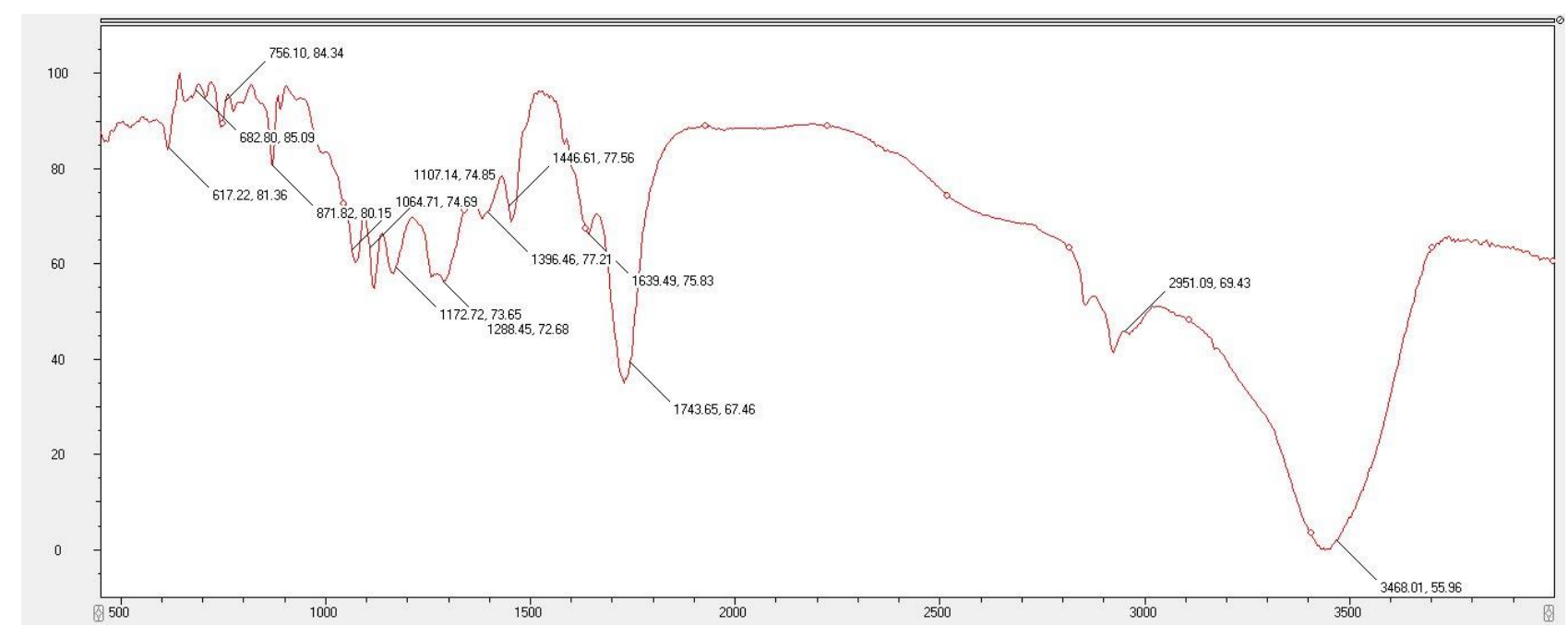

Figure 2. p-PFP-AA IR spectrum

Polymer swelling rate depends on number of factors: nature of polymer and solvent, presence of electrolytes, change of environment $\mathrm{pH}$ and temperature, molecular weight of the polymer, etc. Here, $\mathrm{pH}$ change influence on p-PFP and AA copolymer based hydrogel swelling is studied. Figure shows p-PFP-AA gels with various molar compositions swelling dependence on environment $\mathrm{pH}$ change. It can be seen on the figure that p-PFP and AA copolymer based hydrogels are highly sensitive to environment $\mathrm{pH}$ change (Fig. 2).

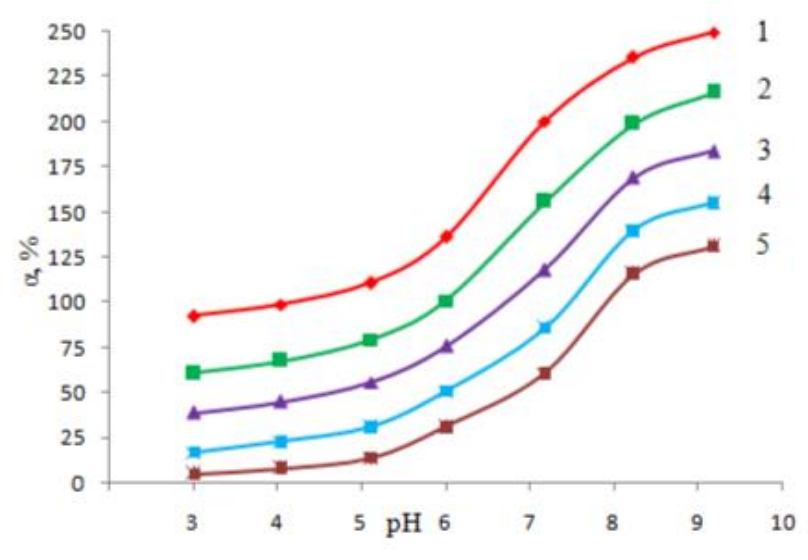

Figure 3. Impact of environment $\mathrm{pH}$ on $\mathrm{pH}$-PFP and AA copolymer based hydrogels volume 
Provided experimental data show that when amount of p-PFP increases in copolymer, gel swelling ability decreases. This is explained by growth of p-PFP chains in initial monomer mixture and reduction of swelling ability due to increase of obtained copolymers cross-linking density. p-PFP-AA based gels dependence curves on figures can be example of hydrogels enriched by acid groups depending on change of medium $\mathrm{pH}$.

Increase of solution $\mathrm{pH}$ leads to improvement of copolymer water-absorbing abilities, which causes rapid growth of hydrogel volume. Switching to medium solution $\mathrm{pH}$ alkaline area does not affect swollen crosslinked polymer conformation. Therefore, p-PFP-AA copolymer hydrogels also show properties of polyelectrolytes containing ionized acid groups with covalent compound in main chain. The main factor defining researched gel swelling is simple electrostatic repulsion of charge $\mathrm{COO}^{-}$groups. Due to large amount of hydrogen ions carboxyl group dissociation can be traced in acid environment and compact subchain extremely close to each other, i.e. defining polymer gel collapse, is formed. Raise of precise saturated area environment $\mathrm{pH}$ leads to carboxyl groups hydrolysis, thus leading to similarly charged functional groups repulsion from each other.

In acid environment carboxyl group dissociation is suppressed, their dense conformation and, as a result, polymer gel collapse are formed. According to experimental data, increase of AA in copolymer leads to increase of gel swelling ability.

In the following research impact of organic solvents on p-PFP-AA 6,77:93,23 mol.\% swelling rate was studied in order to obtain more information about impact of various environment factors on researched saples absorbing ability. As organic components dimethylformamide (DMF), dimethylsulfoxide (DMSO) and ethanol were used; their content in water solution ranged from 0.1 to 1.0 volume ratio $\left(\mathrm{n}_{0}\right)$. Choice of these solvents was based on their polarity difference.

It was found that excessive content of DMSO, DMF and ethanol leads to polymer chains attraction and collapsing. Gel volume in this case depends on elements attraction; this is why volume difference between collapsed and swollen gels increases. Besides, it was found that p-PFP copolymers are also highly sensitive to thermodynamically weak solvents.

In described experiments testing was performed on copolymer samples selected in water and then gradually added into water-organic mixture with pre-set ratio of components. When the polymer swells and the concentration of organic solvent increases to a certain critical amount, the part of the solvent that provides relative stability of the hydrogel is reliably supported by the micromolecules in the form of a solvation layer. This allows to «shift» copolymer contraction to increase of organic components share in water-organic mixture.

As the research results suggest, in case of increasing clarifying tub volume hydrogel swelling ability reduces in water and organic solvent mixture, i.e. this is natural for charged polymer grids in subchains.

Polarity of solvents obtained in the researched work decreases from DMSO to ethanol. It should be noted that polymer swelling in pure organic solvents also follows this pattern.

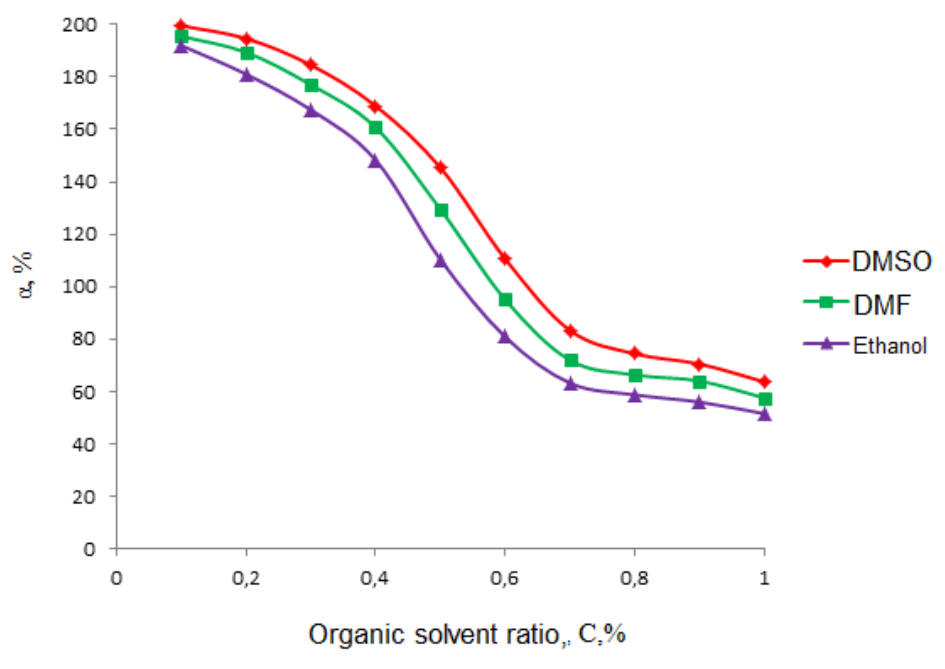

Figure 4. Impact of organic solvents volume ratio (n0) on p-PFP-AA copolymer based hydrogel swelling at molar ratio (20.34:79.66 mol.\%) 


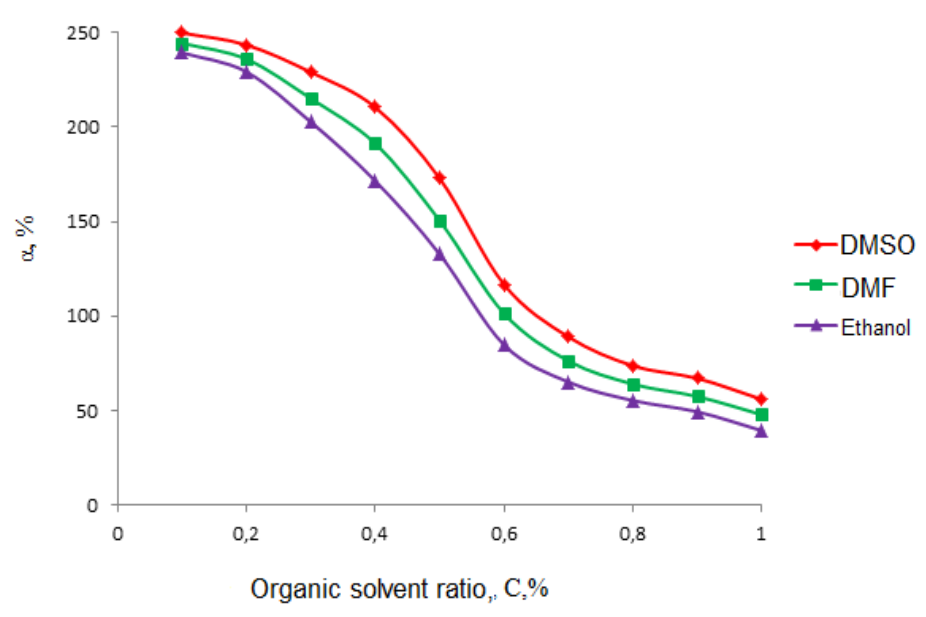

Figure 5. Impact of organic solvents volume ratio (n0) on p-PFP-AA copolymer based hydrogel swelling at molar ratio $(6.77: 93.23 \mathrm{~mol} \%)$

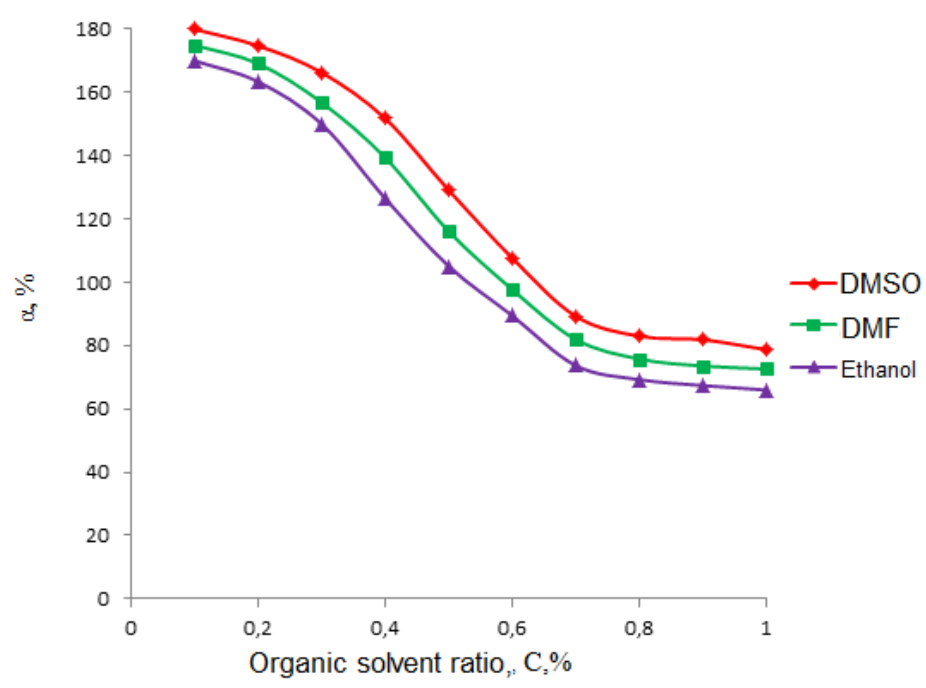

Figure 6. Impact of organic solvents volume ratio (n0) on p-PFP-AA copolymer based hydrogel swelling at molar ratio $(68.42: 31.58 \mathrm{~mol} \%)$

It can be seen at graphs that nature of organic solvent has significant impact on copolymer swelling ability. Hydrogel collapse can be observed in ethanol, where its volume ratio is approximately 0.7 and DMF and DMSO volume ratio is 0.9 . It means that in a low polarity solvent collapse happens immediately, while in a high polarity solvent contraction can be observed. Transition of gel particles from continuity to discreetness in case of organic solvent change corresponds to change of solvent polarity.

\section{Conclusion}

Thus, the conclusion might be made that possibilities of control of physical and chemical properties of polymers based on p-PFP, demonstrated in the work, allow to develop new polymeric materials of polyfunctional destination. Copolymers of poly(propylene fumarate phthalate) and acrylic acid of various molar compositions have been obtained for the first time by radical copolymerization. Synthesized copolymers were identified by IR spectrum data and were defined using high-efficient liquid chromatograph. The results of the study, the influence of various factors ( $\mathrm{pH}=3-9$, solvents DMSO, DMF, ethanol) on the swelling of the polymers showed that the polymers exhibit the properties of polyelectrolytes and can be used as a sorbent in purification and enrichment technologies. 


\title{
References
}

1 Kandelbauer A. Handbook of Thermoset Plastics / A. Kandelbauer, G. Tondi, O.C. Zaske, S.H. Goodman. — San Diego: William Andrew, 2014. - $111 \mathrm{p}$.

2 Kandelbauer A. Unsaturated Polyesters and Vinyl esters / A. Kandelbauer, G. Tondi, S.H. Goodman // Handbook of Thermoset Plastics. - $3^{\text {rd }}$ edition. H. Dodiuk, S.H. Goodman (eds.). — San Diego: William Andrew Publications, 2014. — P. 111-172.

3 Yasko A.W. Injectable biodegradable polymer composites based on poly(propylenefumarate) with poly(ethylene glycol)-dimethacrylate / A.W. Yasko, S. He, P.S. Engel, J.M. Yaszemski, A.G. Mikos // Biomaterials. — 2000. — No. 21. — P. $2389-2394$.

4 Sarsenbekova A.Zh. Comparative analysis of the Thermal Decomposition Kinetics of Polyethylene Glycol Fumarate-Acrylic Acid Copolymers / A.Zh. Sarsenbekova, G.K. Kudaibergen, M.Zh. Burkeev // Russian journal of physical chemistry. — 2019. No. 7(93). - P. 1252-1257.

5 Пот У. Полиэфиры и алкидные смолы / У. Пот. - М.: КТС, 2009. - 380 с.

6 Коляго Г.Г. Материалы на основе ненасыщенных полиэфиров / Г.Г. Коляго, В.А. Струк. — Минск: Наука и техника, 1990. - $143 \mathrm{c}$.

7 Филиппова О.Е. «Восприимчивые» полимерные гели / О.Е. Филиппова // Высокомолекулярные соединения. - 2000. - T. 42, № 12. - C. 2328-2352

8 Holland T.A. In vitro release of transforming growth factor-beta 1 from gelatin microparticles encapsulated in biodegradable oligo(poly(ethylene glycol)fumarate)hydrogels / T.A. Holland, Y. Tabata, A.G. Mikos // J. Control Release. — 2003. — No. 91 . — P. 299-313.

9 Burkeev M.Zh., Tazhbaev E.M., Burkeeva G.K.et al. Effect of External Factors on the Swelling of Hydrogels Based on Poly(ethylene glycol) Maleate with Some vinyl Monomers / M.Zh. Burkeev, E.M. Tazhbaev, G.K. Burkeeva et al. // Russian Journal of Applied Chemistry. - 2013. - No. 1(86). - P. 63-68.

10 Tazhbayev E.M. Enthalpy of swelling of crosslinked copolymers of acrylic acid beta-vinyloxyethylamide in water and ethanol / E.M. Tazhbayev, E.S. Mustafin, M.Zh. Burkeev et al. // Russian journal of physical chemistry. — 2006. — No. 8(80). — P. 13001304.

11 Burkeev M.Zh. Nanocatalytic Systems Based on Poly(ethylene glycol maleate) - Acrylamide Copolymers / M.Zh. Burkeev, E.M. Tazhbaev, G.K. Burkeeva, A.K. Kovaleva // Russian Journal of Applied Chemistry. — 2015. — No. 2(88). — P. 314-319.

12 Burkeev M.Zh. Constants and parameters of radical copolymerization of poly(propylene glycol fumarate)with acrylic acid / M.Zh. Burkeev, Ye.M. Tazhbayev et al. // Bulletin of the Karaganda University. Series Chemistry. — 2019. — No. 1(93). — P. 3237.

13 Burkeev M.Zh. Poly(propylene fumarate phthalate) and acrylic acid radical copolymerization constants and parameters / M.Zh. Burkeev, G.M. Zhumanazarova, G.K. Kudaibergen et al. // Bulletin of the Karaganda university. Series Chemistry. — 2020. No. 1(97). - P. 68-74.

14 Burkeev M.Zh., Kudaibergen G.K., Burkeeva G.K. et. al. The number average and mass average molar masses of polyethylene (propylene)glycol fumarates / Burkeev M.Zh., Kudaibergen G.K., Burkeeva G.K. et. al. // Bulletin of the Karaganda university. Series Chemistry. - 2018. - No. 2(90). - P. 17-22.

15 Гольберт К.А. Введение в газовую хроматографию / К.А. Гольберт, М.С. Вигдергауз. - М.: Химия, 1990. — 352 с.

16 Золотов Ю.А. Физико-химические методы анализа / Ю.А. Золотов, Е.Н. Дорохова, В.И. Фадеева; под ред. Ю.А. Золотова. - М.: Высш. шк., 2000. — 356 с.

\section{М.Ж. Буркеев, Ғ.М. Жуманазарова, Г.Қ. Құдайберген, Е.М. Тажбаев, Г.А. Турлыбек, Э.Ж. Жакупбекова}

\section{Қанықпаған полиэфирлі шайырлар негізіндегі сополимерлерге сыртқы факторлардың әсерін зерттеу}

\begin{abstract}
Мақала поли(пропиленфумаратфталат) және акрил қышқылы негізіндегі сополимерлерге сыртқы факторлардың әсерін зерттеуге арналған. Ұсынылған жұмыста органикалық еріткіштер мен рН ортаның синтезделген сополимерлердің ісіну жылдамдығына әсері зерттелген. Полимердің ісіну жылдамдығы көптеген факторларға байланысты, олардың қатарына: полимердің және еріткіштің табиғаты, электролиттердің болуы, $\mathrm{pH}$ және қоршаған орта температурасының өзгеруі, полимердің молекулалық массасы және т. б. жатады. Жұмыста сополимерлердің полимерлік торының көп бөлігі қанықпаған полиэфирлі шайыр буындарынан тұрады деп болжанған. Зерттеу нәтижелері сополимердегі мономерлік буындардың ара қатынасы полимерлік гельдің ортаның $\mathrm{pH}-ғ а$ қабылдағыштығына және органикалық еріткіштердің (ДМСО, ДМФА, этанол) болуына айтарлықтай әсер ететінін көрсетті. Сомономер қасиеттерінің өзгеруі иондық күштің немесе ерітіндінің термодинамикалық сапасының өзгеруі салдарынан ісінуге немесе сығылуға қабілетті гидрогельдерді алуға мүмкіндік беретіні дәлелденген.
\end{abstract}

Кілт сөздер: полипропиленфумаратфталат, акрил қышқылы, радикалды сополимерлену, полярлы органикалық еріткіштер, ісіну, коллапс, қанықпаған полиэфирлі шайыр. 


\title{
М.Ж. Буркеев, Г.М. Жуманазарова, Г.К. Кудайберген, Е.М. Тажбаев, Г.А. Турлыбек, Э.Ж. Жакупбекова \\ Исследование влияния внешних факторов на сополимеры на основе ненасыщенных полиэфирных смол
}

\begin{abstract}
Статья посвящена исследованию влияния внешних факторов на сополимеры на основе поли(пропиленфумаратфталата) и акриловой кислоты. Авторами изучено воздействие органических растворителей и $\mathrm{pH}$ среды на скорость набухания синтезированных сополимеров. Скорость набухания полимера зависит от множества факторов, к числу которых относятся природа полимера и растворителя, наличие электролитов, изменение $\mathrm{pH}$ и температуры окружающей среды, молекулярная масса полимера и т.д. Предполагается, что полимерная сетка сополимеров по большей части состоит из звеньев ненасыщенной полиэфирной смолы. Результаты исследований показывают, что соотношение мономерных звеньев в сополимере существенно влияет на восприимчивость полимерного геля к $\mathrm{pH}$ среды и присутствию органических растворителей (ДМСО, ДМФА, этанол). Доказано, что изменение свойств сомономера позволяет получить гидрогели, способные набухать или разрушаться вследствие изменения ионной силы или термодинамического качества раствора. Путем варьирования соотношения сомономерных звеньев были отрегулированы интервалы набухания и сжатия полимерных сеток. Молекулярная масса поли(пропиленфумаратфталата) определена методом гель-проникающей хроматографии. Идентификация и состав сополимеров были установлены посредством ИК-спектроскопии и ВЭЖХ соответственно.
\end{abstract}

Ключевые слова: полипропиленфумаратфталат, акриловая кислота, радикальная сополимеризация, полярные органические растворители, набухание, коллапс, ненасыщенная полиэфирная смола.

\section{References}

1 Kandelbauer, A., Tondi, G., Zaske, O.C., \& Goodman, S.H. (2014). Handbook of Thermoset Plastics. San Diego: William Andrew, 111.

2 Kandelbauer, A., Tondi, G., \& Goodman, S.H. (2014). Unsaturated Polyesters and Vinyl esters. Handbook of Thermoset Plastics, $3^{\text {rd }}$ edition. Hanna Dodiuk, Sydney H Goodman (eds.). San Diego: William Andrew Publications, 111-172.

3 Yasko, A.W., He, S., Engel, P.S., Yaszemski, J.M., \& Mikos, A.G. (2000). Injectable biodegradable polymer composites based on poly(propylenefumarate) with poly(ethylene glycol)-dimethacrylate. Biomaterials, 21, 2389-2394.

4 Sarsenbekova, A. Zh., Kudaibergen, G.K., \& Burkeev, M.Zh. (2019). Comparative analysis of the Thermal Decomposition Kinetics of Polyethylene Glycol Fumarate-Acrylic Acid Copolymers. Russian journal of physical chemistry, 7, 93, $1252-1257$.

5 Pot, U. (2009). Poliefiry i alkidnye smoly [Polyesters and alkyd resins]. Moscow: KTS [in Russian].

6 Koliago, G.G., \& Struk, V.A. (1990). Materialy na osnove nenasyshchennykh poliefirov [Materials based on unsaturated polyesters]. Minsk: Nauka i tekhnika [in Russian].

7 Filippova, O.E. (2000). "Vospriimchivye" polimernye heli [“Susceptible" polymer gels]. Vysokomolekuliarnye soedineniia Polymer Science, 42, 12, 2328-2352 [in Russian].

8 Holland, T.A., Tabata, Y., \& Mikos, A.G. (2003). In vitro release of transforming growth factor-beta 1 from gelatin microparticles encapsulated in biodegradable, injectable oligo(poly(ethylene glycol) fumarate) hydrogels. J. Control Release, 91, $299-313$.

9 Burkeev, M.Zh., Tazhbaev, E.M., \& Burkeeva, G.K. et al. (2013). Effect of External Factors on the Swelling of Hydrogels Dased on Poly(ethylene glycol) Maleate with Some vinyl Monomers. Russian Journal of Applied Chemistry, 1, 86, $63-68$.

10 Tazhbayev, E.M., Mustafin, E.S., \& Burkeev, M.Zh. et al. (2006). Enthalpy of swelling of crosslinked copolymers of acrylic acid beta-vinyloxyethylamide in water and ethanol. Russian journal of physical chemistry, 8, 80, 1300-1304.

11 Burkeev, M.Zh., Tazhbaev, E.M., Burkeeva, G.K., \& Kovaleva, A.K. (2015). Nanocatalytic Systems Based on Poly(ethylene glycol maleate) - Acrylamide Copolymers, Russian Journal of Applied Chemistry, 2, 88, 314-319.

12 Burkeev, M.Zh., \& Tazhbayev, Ye.M. et al. (2019). Constants and parameters of radical copolymerization of poly(propylene glycol fumarate) with acrylic acid. Bulletin of the Karaganda University. Series Chemistry, 1(93), 32-37.

13 Burkeev, M.Zh., Zhumanazarova, G.K., \& Zhakupbekova, E.Zh. et al. (2020). Poly(propylene fumarate phthalate) and acrylic acid radical copolymerization constants and parameters. Bulletin of the Karaganda University. Series Chemistry, 1(97), 68-74.

14 Burkeev, M.Zh., Kudaibergen, G.K., \& Burkeeva, G.K. et al. (2018). The number average and mass average molar masses of polyethylene (propylene)glycol fumarates. Bulletin of the Karaganda University. Series Chemistry, 2(90), 17-22.

15 Golbert, K.A., \& Vigdergauz, M.S. (1990). Vvedenie v hazovuiu khromatohrafiiu [Introduction to Gas Chromatography]. Moscow: Khimiia [in Russian].

16 Zolotov, Yu.A., Dorokhova, E.N., \& Fadeeva, V.I. (2000). Fiziko-khimicheskie metody analiza [Physico-chemical methods of analysis]. (Eds. Yu.A. Zolotov) Moscow: Vysshaia shkola [in Russian]. 